\title{
The Histology of the Sieve Tubes of Pteridium aquili- num, with some Notes on Marsilia quadrifolia and Lygodiumdi chotomum.
}

\author{
BY \\ E. M. MARGARET HUME, \\ Bathurst Student of Neronham College, Cambridge.
}

With Plates LIV and LV.

W re-examination of the sieve tubes of any Vascular Cryptogam has been been introduced. It seemed therefore desirable to make an examination which would render possible a comparison between the sieve tubes of some Vascular Cryptogam and those of certain Angiosperms ${ }^{1}$ and of Pimus, ${ }^{2}$ as worked out by A. W. Hill, and of Macrocystis and Laminaria, ${ }^{3}$ as worked out by M. G. Thoday (Sykes).

\section{HISTORICAL.}

De Bary," in his 'Comparative Anatomy of Phanerogams and Ferns', seems to have been the first to recognize the parietal layer of protoplasm which forms the characteristic lining of the sieve tubes of Vascular Cryptogams. He also noticed that the refringent granules contained in the protoplasm were aggregated against the sieve plates, and figures ${ }^{5}$ a connexion between granules of adjacent sieve tubes, across the pit-closing membrane. De Janckzewski ${ }^{6}$ also mentions the presence of the refringent granules, as do most persistently all writers upon the subject. He mentions that starch is very rarely present in the sieve tubes of either Vascular Cryptogams or Monocotyledons; the latter, he says, also possess the refringent granules. He recognized that portions of the pit-closing membrane in Pteridium aquilinum give the same reactions as the callus of Angiosperms, but he regarded it as quite exceptional among Vascular Cryptogams, and held that their sieve plates are really unperforated.

Russow ${ }^{7}$ confirmed de Janckzewski's observation of the presence of refringent granules in Monocotyledons. His examination of Vascular Crypto-

\footnotetext{
1 Hill ('08).

${ }^{2}$ Hill ('01).

${ }^{3}$ Sykes ('08).

4 De Bary ('84), pp. I80-2.

${ }^{6}$ De Janckzewski ('82), pp. 59-65.

5 De Bary, loc. cit., Fig. 79 B.

7 Russow ('82), p. 207.
}

[Annals of Botany, Vo1. XXVI. No. CII. April, 1912.] 
gams was not very extensive, but he observed the presence of callus in most Ferns, with the exception of the Marattiaceae and Ophioglossaceae, and noticed that the refringent granules adhere to the free ends of the callus rods. He came to the conclusion that the sieve plates are perforated, but does not seem to have been able to demonstrate both callus rods and connexions at the same time.

Poirault, ${ }^{1}$ in the course of his extensive researches into the structure of Vascular Cryptogams, also came to the conclusion that the sieve plates must be perforated by connecting threads, but he too was unable to prove it; neither could he determine whether the paired callus plugs, on either side of the sieve plate, were or were not continuous with one another across the middle lamella.

The question has remained in this uncertain condition ever since, as far as the Vascular Cryptogams are concerned. The only additional observations worthy of note are due to Boodle, ${ }^{2}$ who, using Grubler's azoblue as a callus reagent, showed the widespread presence of callus among the Ferns, with the exception of the Schizaeaceae, Hymenophyllaceae, and, as he at first thought, of the Gleicheniaceae. Examination of material of the rhizome of Gleichenia pectinata, which had not been allowed to come into contact with spirit, revealed the presence of callus, ${ }^{3}$ and suggested the probability of its presence in the other two orders as well, if suitable material and methods could be found to demonstrate it. Boodle ${ }^{4}$ mentions that the refringent granules are 'often distinctly grouped on the sieve plate'. The question of the perforation of the sieve plates was not attacked by him, but the callus is described as a rod running through the wall, and having expanded heads. He also notes the presence of callus in the pits between sieve tubes and phloem parenchyma cells.

In Pinus ${ }^{5}$ and the Angiosperms, ${ }^{6}$ A. W. Hill has traced the development of the connexions between adjoining sieve plates. He has shown that, in their earliest condition, these appear as delicate protoplasmic threads, with a darkly staining node. Later, probably by the action of ferments working along them, the threads become converted into thicker slime strings, while, at the same time, the cellulose of the cell-wall immediately surrounding the slime string is altered into callus. Several slime strings may be contained in the same callus rod, as in Pinus, or each string may have its own callus rod (Vitis). It is only the cellulose portion of the cell-wall which becomes converted into callus; hence the callus does not form a continuous rod right across the pit-closing membrane, but is interrupted at the middle lamella. Here, however, the ferments also bring about some change, and immediately round each median protoplasmic node the pectic

1 Poirault ('93), pp. I9I-5.

3 Boodle, loc. cit., p. 708.

5 Hill ('01).
${ }^{2}$ Boodle ('01), pp. 395-9.

4 Boodle, loc. cit., p. 397 .

${ }^{6}$ Hill ('08). 
substances of the middle lamella become altered, so that they stain darkly with protoplasmic dyes. The portion of the middle lamella which is thus altered separates the callus rod into two halves, and is called the median nodule. The slime strings may be further bored out until they become very thick, and meanwhile the median nodule is apparently dissolved away and callus deposited as a tubular lining right across the pit-closing membrane. In $W$ istaria the wall between adjoining slime strings may be completely dissolved away, and several small strings may coalesce to form one large one. In Vitis the original slime strings remain independent. Callus is present on the sieve tube side of the pits connecting sieve tubes and bast parenchyma cells. The sieve tubes of Vitis function from year to year, and become plugged during the winter with callus, which is dissolved away in the following spring when the phloem resumes its activity.

In the light of the foregoing facts, an examination of the sieve tubes of Pteridium aquilinum was undertaken in order to determine whether the protoplasm of adjacent sieve tubes is, or is not, continuous across the sieve plate, and if it is so, what relation such a connexion bears to the distribution of the callus. It was also hoped, if possible, to throw some light upon the nature of the refringent granules. Pteridium aquilimum was chosen for the purpose, because it possesses exceptionally large sieve tubes ; for the same reason Marsilia quadrifolia was also selected. In the latter case everything seems to indicate that the development of the sieve tubes closely resembles that of Pteridium, but the actual sequence of development was not worked out. The absence of secondary thickening in Ferns makes the accurate seriation of the various developmental stages of the sieve tubes a rather tedious business, as a number of blocks have to be cut, and after preparation the stages contained in them are often found to be only duplicates of those already obtained. The development was worked out in the rhizome, as it contains all the older stages as well as the young ones.

\section{METHODS OF RESEARCH.}

The methods used were, in the main, those introduced by W. Gardiner ${ }^{1}$ and adapted by A. W. Hill ${ }^{2}$ and M. G. Thoday. ${ }^{3}$

A dilute solution of iodine in potassium iodide was used for fixation, and swelling was effected by treatment, for two or three weeks, with a much stronger solution of iodine. Kolossow's mixture was used for mordanting, and for staining, safranin and London blue. Excess of safranin was washed out in dilute glycerine, and the washing-out process is continued in the London blue. ${ }^{4}$ In cases where staining with safranin was insufficient the sections

1 Gardiner ('97), p. 100; ('98), p. 504.

3 Thoday (Sykes) ('08, '11).

${ }^{2}$ Hill ('01, '08).

4 For the use of this stain as a callus reagent and for washing out safranin from cell-walls, see Sykes ('08), p. 299. 
were remordanted in dilute iron alum and stained in water blue made up with aniline. ${ }^{1}$

The material of Marsilia quadrifolia and Lygodium dichotomum was obtained from the University Botanic Garden, by the kindness of the Curator; that of Pteridium aquilinum was collected in Gamlingay Wood.

\section{Distribution and General Characters of the Sieve TUBES.}

Both in Marsilia and in Pteridium the sieve tubes are characterized, as has already been stated, by their remarkable size (Pl. LV, Fig. 32).

In Pteridium they occur as a complete ring surrounding the xylem in each of the vascular strands of the rhizome (Pl. LV, Figs. $3^{\mathrm{I}}$ and $3^{2}$ ). The vascular strands are flattened dorsiventrally, corresponding to the horizontal position of the rhizome, and it is on the dorsal and ventral sides of these strands that the phloem attains its greatest development. Laterally it is much thinner, the phloem elements being very small and scarcely distinguishable from the protophloem. The ring of large sieve tubes is very regular, and is not usually more than one cell thick, so that each sieve tube abuts on another on either side of it, but centrifugally and centripetally it abu s upon phloem parenchyma, protophloem, or pericycle (PI. LV, Figs. 3 I and 32 ). The sieve plates of the lateral walls, therefore, occur almost invariably upon the radial walls, i. e. between two sieve tubes, and being in Pteridium of frequent occurrence, they form a very perfect, continuous conducting channel round each of the vascular strands. The importance of this will be realized when it is recalled that the roots occur all along the ventral side of the rhizome, while a single frond is given off laterally each year; there is no aggregation of roots and leaves at a definite node, as will be described in Marsilia.

The protophloem (Pl. LV, Fig. 29) occurs as an almost continuous ring of very small and, in the mature state, thick-walled elements, situated just outside the ring of large sieve tubes. Irregularly distributed, and abutting on the tangential walls of the sieve tubes, are the phloem parenchyma cells (Pl. LV, Fig. $3 \mathrm{I}$ ), which are elongated, with dense contents and a large elongated nucleus. Pits can be seen in the walls between sieve tubes and phloem parenchyma cells (Pl. LV, Figs. 30 and 32 ). The pericycle is generally one cell thick, and the cells are very obviously sister cells of the endodermis. Pits are particularly abundant on the tangential walls between pericyclic and endodermal cells. As regards the general characters of the mature sieve tubes, they are large, very thick-walled elements, with a thin parietal layer of protoplasm containing refringent granules. The lumen of the cell appears empty in cross section, but no doubt, in life, the contents 
are a watery fluid. The terminal walls of the sieve tubes are generally very much inclined (Pl. LIV, Fig. 26 ), so much so that in longitudinal section they are often indistinguishable from the lateral walls. Both in the terminal (P1. LIV, Fig. I3) and in the lateral (P1. LIV, Fig. I4) walls large thin areas occur; these are the sieve plates. They are generally more numerous on the terminal walls, but no definite rule can be laid down, and it is almost impossible to distinguish with absolute certainty between a lateral wall with numerous large plates and a terminal wall with few small ones; the two classes merge into one another, and a separation of the two types is not founded on any fundamental difference in their structure. In a transverse section terminal plates can often be distinguished by the fact that they may run right across the diameter of what would otherwise be a single circular sieve tube, dividing it into two elements, each having a half-moon-shaped cross section (Pl. LIV, Fig. 26). The distinction of sieve areas into sieve fields and sieve plates, employed by Hill in describing the Phanerogams, will not be of value here, since there is no sharp differentiation of the two types. The development of sieve plates on the terminal walls is sometimes very extensive indeed, the major part of the wall being thin, and the thickened portion consisting only of bars of cellulose running transversely from side to side of the wall; such a wall is very reminiscent of that of a tracheide.

In Marsilia the general relations do not differ very materially; the stele is a solenostele in which the sieve tubes form two fairly regular concentric rings, or rather two pairs of arcs, for laterally phloem development is feeble as in Pteridium. The sieve tubes have somewhat thicker walls than those of Pteridium, but in general appearance they resemble them very markedly. The development of sieve plates on the lateral walls of the internodes is not so extensive as in Pteridium, and gives more the impression of scattered pits. At the nodes, however, the lateral sieve plates seem to be developed fully. This is interesting in view of the fact that roots are developed at the nodes only in Marsilia quadrifolia, roots, petiole, and sporocarp all growing out at the same level round the procumbent rhizome. There is, therefore, a special demand for conduction around the stem at the nodes, while the internodes are comparatively passive in this respect. Russow ${ }^{1}$ asserts that terminal walls in the sieve tubes occur, as a rule, only at the nodes, the tube running unbroken from node to node, but this statement has not been found to be correct. Terminal walls are not very frequent in the internodes, but they do occur. They are often considerably inclined, which may have caused Russow to overlook them ; and they bear numerous sieve plates; in other details the phloem of Marsilia quadrifolia does not differ materially from that of Pteridium.

\footnotetext{
1 Russow ('72), p. 5 .
} 


\section{HISTOLOGY.}

In the earliest stages of development of the sieve tubes of Pteridium aquilimum, the same difficulties of observation were experienced as seem to have been encountered by A. W. Hill. The walls of the sieve tubes, at an early age, are thin (P1. LV, Fig. 29), and it is not until they have undergone quite a marked increase in thickness that it becomes possible to demonstrate the presence of threads traversing the walls. The contents of the sieve tubes are at first quite considerable, consisting of rather darkly staining protoplasm, which tends to contract very easily with any reagents and, in transverse section, often falls out altogether. Such behaviour would probably rupture the connecting threads, but even in cases where the contents are still present and are little or not at all contracted, no certain indications can be seen of any connexions. As the diameter of the sieve tube increases the protoplasm becomes more and more drawn out into a thin layer, lining the walls, to which it is very closely applied. The walls are by this time considerably thickened, the areas of the sieve plates are mapped out, and in particularly favourable cases, delicate protoplasmic threads may be seen crossing the membrane (Pl. LIV, Fig. I). At the middle lamella they show a rather more darkly staining protoplasmic node. The recognition of the protoplasmic threads before the appearance of callus is extremely difficult in the large sieve tubes, but it is easier in the elements of the protophloem. These elements become very much thickened, and show deep pits with long drawn-out pit fillings. Callus often cannot be detected at all; in fact it would appear as if the protophloem elements were not much used by the plant, and retain their juvenile characters right through life (Pl. LIV, Figs. 2 and 3). The connecting threads in the sieve plate are not as a rule aggregated into groups, but are dotted about singly all over the sieve plate. Up to, and even after, the first appearance of callus the refringent granules so often described appear to be small and distributed through the sieve tube, though mainly collected about the sieve plates (P1. LIV, Fig. 1). It cannot be said with absolute certainty that, at this stage, they bear a definite relation to the threads, since they often appear to have no connexion with them; how far this can be attributed to disturbance brought about by cutting, however, it is not very easy to say.

The callus appears first as a shallow basin about the head of each thread (Pl. LIV, Fig. 4); callus formation seems generally to take place simultaneously on both sides of the pit-closing membrane, though some instances ${ }^{1}$ were observed in which it was advanced further on one side than on the other (Pl. LIV, Fig. 4). Callus formation advances from either side towards the middle lamella, but stops short at it, while a corresponding

\footnotetext{
${ }^{1}$ Cf. Sykes ('08), Pl. XIX, Fig. I5 ; and Hill ('08), Pl. XVII, Fig. 24.
} 
alteration of the substance of the middle lamella between the callus plugs takes place. This change in the middle lamella causes it to have the property of staining with protoplasmic dyes, and after treatment with safranin the altered places are very conspicuous as red dots (Pl. LIV, Figs. 5 and 6). The threads stain more darkly at this stage, but are still very slender, so that they are not very conspicuous; before treatment with London blue they can generally be traced fairly easily, but after the callus has been stained, the deep blue colour is often sufficient to obliterate the outline of the slime strings altogether (Pl. LIV, Fig. 4). Each slime string possesses its own distinct pair of callus basins (Pl. LIV, Fig. 9), though when two slime strings are sufficiently near together their callus basins may touch one another, and give the appearance of more than one string contained in a single mass of callus (Pl. LIV, Fig. 6). Soon after this stage has been reached, it is quite apparent that the arrangement of the refringent granules bears a very definite relation to that of the slime strings and callus basins (P1. LIV, Fig. I2). The granules are larger than in the earlier stages, and their appearance suggests that they are more of the nature of mucilaginous droplets than of granules. A refringent granule is attached to each end of the slime string (P1. LIV, Figs. I2 and I7), and in a section of a sieve plate each slime string has the appearance of a hatpin with a knob at each end. Whether, however, the callus is of a sticky nature and causes the granules to adhere, or whether they are actually connected with the slime strings, could not be determined. In a surface view of a sieve plate the refringent granules, which stain darkly with safranin, make the callus basins invisible (P1. LIV, Figs. I 3 and I4), though on focusing carefully the granules take a mauve tinge, due to the blue of the callus below them; in sections of this stage, stained in London blue only, there can be seen successively, on focusing downwards, the clear outline of the upper refringent granule, then a blue spot (the callus rod), and lastly the outline of the lower refringent granule. In sections stained with both London blue and safranin the callus can only be seen here and there in surface view as a blue spot, where the refringent granule above it has been dislodged (Pl. LIV, Figs. I 5 and I 6 ); in such cases the median nodule can be focused as a red spot in the midst of the blue (Pl. LIV, Fig. I5). The median nodule is also visible as a dark spot on focusing down through the granules (Pl. LIV, Fig. I5). The granules seem to grow larger after their attachment to the ends of the slime strings becomes apparent (Pl. LIV, Fig. I6). When this stage becomes visible the callus basins begin to be dissolved away (P1. LIV, Figs. I 8 and I9), possibly through the action of the granules, which sink down into the cavity left by the disappearance of the callus. The median nodule, also, next becomes entirely dissolved away, so that there is now a thick slime string (Pl. LIV, Figs. I 8-26) stretching uninterruptedly across the pit-closing membrane, and derived apparently, in part at least, from the refringent granules or mucilaginous 
droplets of each end of the slime string. The solution of the callus does not always go on quite at the same rate all over the same sieve plate, so that various stages of the sinking in of the granules may be observed. Sometimes the sinking in has not proceeded quite at the same rate (Pl. LIV, Fig. I9) on both sides of the plate; and sometimes the granule becomes dislodged by cutting after it has sunk in some distance, and the deep pit into which it had sunk then becomes visible (Pl. LIV, Fig. 24); the pit thus left empty has noticeably the same shape and size as the callus basin from which it was derived. Whether the callus always becomes completely dissolved away, or whether a thin shell or tubule is sometimes left, is not quite certain. Certainly stages were often seen in which no remaining trace of callus could be detected, but others were also observed in which a very faint blue tubule could be seen before the slime string was stained in safranin. Probably the solution is ultimately completed, and as far as could be seen no redeposition of callus ever takes place. Portions of the rhizome, which must have been many years old, were examined and the sieve tubes were found to be still functional; thick slime strings, such as those described above, generally perforated the sieve plates; in a few places traces of callus were observed still, but there is little doubt that these represent paths, which, for some reason or another, have not functioned very extensively. The whole aspect of the sieve plates suggests most strongly that it is as the result of use that much of the foregoing process of evolution is gone through. Thus the most rapidly developed slime strings represent the most frequented paths, and in support of this view it may be mentioned that in the terminal plates, which necessarily see the most service, the development is most rapid.

In the pits connecting sieve tubes with phloem parenchyma cells (Pl. LIV, Figs. 27 and 28), callus was never observed, ${ }^{1}$ even in elements in which it was fully developed in the sieve plate. The pits are simple depressions of considerable depth, usually containing a single connecting thread. The wall of the sieve tube being a great deal thicker than that of the adjoining parenchyma cell, the middle lamella is asymmetrically placed, lying very much nearer to the lumen of the parenchyma cell than to that of the sieve tube. The connecting thread can be seen as a granular protoplasmic filament running to the middle lamella, where there is a dark dot-the median node. The wall between the lumen of the parenchyma cell and the middle lamella is so extremely thin that the detection of any pit or thread on that side is very difficult, but in some cases they can be seen to exist. It would seem, therefore, as if there is no boring out of the thread even on the sieve tube side, such as $\mathrm{Hill}^{2}$ has described for Pinus and the Angiosperms, and his view that the ferment action is initiated

1 Contrast Hill ('01), P1. XXXIII, Fig. 23, and pp. 600-2, and Hill ('08), P1. XVIII, Figs. 50, 5I, 52, and pp. 278-80.

2 Hill ('08), p. 28 I. 
within each sieve tube, and necessarily works outward in all directions towards the middle lamella, would hardly be supported by the facts in Pteridium. Of course it may be that callus does occur very transiently in these pits at some stage, examples of which have not been hit upon. This seems hardly probable, as, did it occur, the most likely place would be in sieve tubes where the sieve plates show the presence of callus; but in these no callus was found in the pits in question. If the slime strings become bored out by use, by the travelling of ferments and other substances along them, it seems strange that the same process should not take place in the case of threads leading into the phloem parenchyma cells, which have every appearance of being in a state of activity.

Accumulations of callus (Pl. LIV, Figs. Io and II) were occasionally observed, but their presence could not be connected with any particular stage in development, nor was their distribution at all regular; possibly their formation is attributable to some pathological condition in the particular elements in which they were found. Callus formation is generally entirely limited to the paired basins connected with each slime string. Material was gathered in December and examined for accumulations of callus, blocking the sieve tubes during the winter rest, but no evidence of anything of the kind could be seen. Sections were examined, from the apex of the rhizome backwards to regions as much as five years old (the giving off of a frond being taken as an annual event), and in no part was a development of callus beyond the ordinary detected. It does not seem therefore as if any blocking of the sieve tubes during winter takes place.

\section{MARSILIA QUADRIFOLIA.}

No systematic examination of Marsilia was made, as has been stated already, but the stage at which callus is developed was detected, and everything indicated that the mucilaginous droplets behave in the same way as in Pteridium. The lateral plates in the internodes are few and small, often taking the form of isolated threads in pits; they seem to be but little used, as even in sections of comparatively older material their threads appear to be granular, protoplasmic, and unaffected by ferments.

Some material of Lygodium dichotomum was also examined, especially in order to investigate the presence or absence of callus, in view of Boodle's inability to demonstrate it in the Schizaeaceae. ${ }^{1}$ None could be detected, but, as the material available was all of nearly the same age, this was not surprising. Preparations stained with safranin were not made, so that no definite statements can be made as to the perforation of the sieve plates, but the aspect of the unstained sieve tubes suggested that they did not differ materially from those of Marsilia and Pteridium. 


\section{CONCLUSIONS.}

According to de Janckzewski, as summarized by Russow, ${ }^{1}$ the sieve tubes of Vascular Cryptogams differ from those of Phanerogams in their shape, in the absence of callus, and in the fact that the pores of the sieve plate are always closed. Russow was able to show that Cryptogams are not characterized by the absence of callus from their sieve tubes, and the foregoing account shows that the pores are not closed, but are as open as they are in Phanerogams ; and that the process of development is similar in many ways. The outstanding differences therefore are in shape and contents; the sieve tubes of Vascular Cryptogams are larger and thicker walled and contain refringent granules.

The size of the sieve tubes and the thickness of their walls in Vascular Cryptogams are, it would seem, very likely dependent on the fact that, owing to the absence of secondary thickening, they have to function for a long time, in some cases for as much as twenty years, while in some Dicotyledons and Gymnosperms they are renewed each year. In some Phanerogams (as in Vitis), it is true that they do function for more than one year, after being blocked with callus in the winter. Vitis, being a climber, perhaps needs more than the average amount of phloem, and therefore makes use of more than the current year's growth of phloem. It was suggested to the writer that the absence of blocking by callus in winter in Pteridium might be due to the fact that the rhizome is an underground organ, and is therefore not so severely affected by the frost as an aerial one would be. With a view to determining whether this theory is borne out by the state of affairs in other underground organs, a rapid examination was, made of winter material of the roots and stem of Vitis vinifera. The sieve tubes of the stem showed the great pads of callus blocking the sieve plates which Hill has described, ${ }^{2}$ but in the roots no such pads could be found, and the sieve tubes showed masses of slime pressed against the sieve plate, the pores of which were clearly traversed by the slime strings. Little doubt, therefore, seems to exist that the sieve tubes of Pteridium remain unblocked by callus in winter because the rhizome is a completely subterranean organ and is, on that account, not subjected to the severities of weather to which an aerial organ would be exposed during the winter.

The facts ascertained concerning the finer histological details of the sieve tubes of Pteridium aquilinum correspond closely with Hill's observations on Pinus and the Angiosperms. The presence of the protoplasmic threads in the early stages, and the way in which they are bored out to form slimestrings associated with callus, are all materially the same. The salient differences are the ultimate total disappearance of the callus while the sieve

1 Russow ('82), p. 208.

${ }^{2}$ Hill ('08), pp. $275^{-6}$, and Pl. XVIII, Figs. $4^{\mathrm{I}}$ and 54 . 
tube is still functional, and the presence and behaviour of the mucilaginous droplets, which still remain somewhat of an enigma. The fact that the droplets or granules occur in Monocotyledons also, and that in the early stages of the development of the sieve tubes in Vascular Cryptogams they cannot be distinguished in the granular mass of protoplasm forming the contents of the sieve tubes, seems to suggest that their manifestation may be connected in some way with the prolonged functioning of the sieve tubes. Their general behaviour and appearance suggest that they are viscous drops of slime akin to the substance of the slime strings, but whether they really function in the formation of the slime string, or whether they merely sink mechanically into the pits left by the solution of the callus, cannot be affirmed absolutely ; their final fate would certainly appear to be incorporation in the substance of the slime string. It is possible that they are attached to it $a b$ initio, and are at first very small, and that afterwards they gradually swell until their relationship to it is easily discernible. In that case they would seem to be simply the swollen heads of the slime strings. The separate individuality of the mucilaginous droplets would naturally become more clear as the parietal layer of protoplasm becomes thinner, consequent upon the increase in size of the sieve tube.

The constant connexion of the droplets with the sieve plate was noticed by both Russow ${ }^{1}$ and de Bary, ${ }^{2}$ and the latter figures the droplets as connected with one another by threads crossing the sieve plate.

With regard to the callus, it cannot be disputed that there is no very great development of callus in Vascular Cryptogams. In the life-history of each sieve tube, however, in Pteridium, at any rate, there is a stage at which callus is quite abundant and easily detected. An observer, examining material in the stages before callus formation or after its dissolution, would be disposed to say that callus was absent, and this no doubt led to the contradictory statements that were for a long time made upon the subject. The stage in which callus is present does not seem to last very long ; the amount of the rhizome of Pteridium in which this stage is to be found would therefore be comparatively small in relation to the total mass, and the chance of the region containing callus being overlooked would be considerable. The same is true of Marsilia quadrifolia ; many sections were examined, and the callus stages were only present in a few. No stages with callus were found in Lygodium dichotomum, but the material examined was all derived from petioles of approximately the same age, so that the absence of callus was not surprising ; examination of a sufficient quantity of material of varying ages would very likely reveal it. Boodle records his inability to detect callus in the Schizaeaceae, attributable probably to the same cause, as the general appearance of the sieve tubes in Lygodium, though they are

1 Russow ('82), p. 209.

2 De Bary ('84), Fig. 79 B.

Q q 2 


\section{Hume. - The Histology of the Sieve Tubes of Pteridium}

smaller, does not suggest that their development is likely to differ fundamentally from that in Pteridium.

The short duration of the stage in which callus can be detected, in the sieve tubes of those Vascular Cryptogams examined, confirms the view advanced by other authors, ${ }^{1}$ that callus can be formed as an early stage in the solution of the cellulose of the wall. The existence of callus in various states of aggregation or hydration is mentioned by Mangin ${ }^{2}$ and M. G. Thoday $;^{3}$ these different states perhaps represent different stages of solution. Deposition of callus directly from the protoplasm does not seem to occur in Pteridium, unless the exceptional cases figured in Pl. LIV (Figs. Io and II) originated in that way.

\section{SUMMARY.}

I. The distribution of the sieve tubes and sieve plates in Pteridium aquilimum provides for conduction all round the vascular strand, both in the node and internode. In Marsilia quadrifolia, conduction around the stem is especially provided for in the nodes, but in the internodes there is very little provision for it. The variations in the distribution of the sieve plates in the two types are connected with the association together of the leaf, roots, and sporocarp at the node in Marsilia, while in Pteridium the roots have no regular distribution in relation to node and internode.

2. The sieve plates in Pteridium aquilinum are traversed at the earliest stage by delicate protoplasmic threads, each with a median protoplasmic node.

3. Callus is developed as a pair of basins in connexion with each individual thread, and the middle lamella between the callus basins becomes altered to form the median nodule.

4. The protoplasmic thread begins at the same time to be bored out to form a slime string, and at this stage the refringent granules or mucilaginous droplets can be seen to be arranged regularly, one at each free end of each slime string.

5. The callus next becomes dissolved away, and the mucilaginous droplets sink down into the cavities thus left.

6. Finally, the median nodule becomes dissolved away, and a homogeneous thick slime string is produced, derived partially, as far as can be seen, from the paired mucilaginous droplets.

7. The sieve tubes function for years, but no callus seems to be deposited in winter to block them. This is very probably because the rhizome of Pteridium is a subterranean organ. Winter material of the roots and stems of Vitis vinifera showed callus blocking the sieve tubes in the stem, but not in the root.

1 Oliver ('87), p. I I 2 ; Hill ('01), pp. 597-600; Hill ('08), p. 278 ; Thoday ('11), p. 673.

2 Mangin ('92), p. 263.

3 Thoday ('11), p. $3^{\mathrm{I}} 5$. 
8. Connexions between sieve tubes and phloem parenchyma cells are frequent, but no callus was ever detected in connexion with them.

9. From a limited examination, the impression was received that the development of the sieve tubes in Lygodium dichotomum and Marsilia quadrifolia resembles that in Pteridium aquilinum.

My thanks are due to Mrs. Thoday, to whom I am deeply indebted for her never-failing kindness and counsel, and for an initiation into histological methods of research.

Botany School, Cambridge, igit.

\section{BIBLIOGRAPHY.}

Boodle, L. A. : Anatomy of the Schizaeaceae. Ann. Bot., xv, I90I, p. 395 .

DE BARY, A. : Comp. Anat. (Eng. edit.). Oxford, I 884

Gardiner, W.: The Histology of the Cell-wall with a Special Reference to the Mode of Connection of the Cells. Roy. Soc. Proc., lxii, 1897.

: Method for the Demonstration of 'Connecting Threads' in the Cell-wall. Proc. Camb. Phil. Soc., 1898 .

Hill, A. W.: The Histology of the Sieve Tubes of Pinus. Ann. Bot。, xv, I90I. : The Histology of the Sieve Tubes of Angiosperms. Ann. Bot., xxii, I 908.

DE Janckzewski, E. : Études comparées sur les tubes cribreux. Ann. des Sci. Nat., Bot., sér. vi, t. xiv, I 882 .

Mangin, L. : Observations sur la présence de la callose chez les Phanérogames. Bull. Soc. Bot. de France, t. xxxix, I892.

Oliver, F. W.: On the Obliteration of the Sieve Tubes in Laminarieae. Ann. Bot., i, I887.

Poirault, G.: Recherches anatomiques sur les Cryptogames vasculaires. Ann. des Sci. Nat., Bot., sér. vii, t. xviii, 1893 .

Russow, E.: Vergleichende Untersuchungen der Leitbündel-Kryptogamen. St. Petersburg, 1872. : Sur la structure et le développement des tubes cribreux. Ann. des Sci. Nat., Bot., sér. vi, t. xiv, I882. (Translated from Sitzb. d. Dorpat. Nat. Ges., I882).

Sykes, M. G. : Anatomy and Histology of Macrocystis pyrifera and Laminaria saccharina. Ann Bot., xxii, 1908.

Thoday (SyKes), M. G. : On the Histological Relations between Cuscuta and its Host. Ann. Bot., xxv, I9II.

\section{EXPLANATION OF PLATES LIV AND LV.}

Illustrating Miss Hume's paper on the Sieve Tubes of Pteridium aquilinum.

PLATE LIV.

Lenses used were Swift's $\frac{2}{8}$ 'apochromatic' objective, with 6,8 , and I 2 Zeiss's compensating oculars. Staining was with safranin and London blue except where otherwise stated. The blue colour in the figures represents callus. The figures throughout are of Pteridium aquilinum.

Fig. I. Longitudinal section of portion of sieve plate, abutting on parenchyma cells on the right of the figure, on another sieve tube on the left. Protoplasmic threads, showing a median node 


\section{Hume.-The Histology of the Sieve Tubes of Pteridium}

traverse the lateral sieve plates. A certain amount of granular protoplasm lines the sieve tube and is aggregated at the sieve plate. $\times 650$.

Fig. 2. A group of protophloem elements in longitudinal section. The contents are comparatively dense, especially in the pits. The middle lamella is not visible, and only one of the protoplasmic threads shows a median node. $\times 6_{50}$.

Fig. 3. Longitudinal section of two protophloem elements connected by protoplasmic threads. Middle lamella and median nodes are faintly visible. $\times 730$.

Fig. 4. Transverse section of two adjoining sieve tubes. Aggregation of the granules is more marked and callus formation has commenced on both sides of the plate, but has advanced somewhat further on one side than on the other. Alteration of the middle lamella to form the median nodule has begun, and the staining of the threads is darker. $\times 600$.

Fig. 5. Transverse section. A very common aspect of stages containing callus, in which only the median nodule and the paired callus basins can be seen. The layer of protoplasm covering the plate is thicker but less granular than usual. $\times \mathrm{I}, 000$.

Fig. 6. Transverse section, showing groups of paired callus basins with their median nodules in the same stage as Fig. 5. The large empty lumen and parietal layer of protoplasm of the sieve tubes and the dense contents of the abutting phloem parenchyma cells are shown. $\times 55^{\circ}$.

Fig. 7. Longitudinal section, showing lateral sieve plates of radial wall in surface view. Stained with London blue only so that the callus basins alone are shown as blue dots. (Semidiagrammatic.)

Fig. 8. Longitudinal section, showing a much inclined terminal wall in suface view. Cf. Fig. 7 ; the sieve plates are larger and much more numerous than in a radial wall. Stained with London blue only. (Semi-diagrammatic.)

Fig. 9. Longitudinal section of a sieve tube wall bearing numerous sieve plates. Callus basins and median nodules have been developed and the protoplasmic threads are undergoing conversion into the more darkly staining slime strings. Granules in some cases show attachment to slime strings. $\times 650$.

Fig. 10. Longitudinal section, showing a much inclined terminal wall in surface view. An exceptional case in which there is a considerable development of callus over the surface of the plate. The granules show a regular arrangement in relation to the ends of the slime strings. $\times 700$.

Fig. II. Transverse section of group of abutting sieve tubes, showing accumulations of callus on two lateral sieve plates. $\times 480$.

Fig. 12. Longitudinal section of a lateral wall with numerous sieve plates; a slightly more advanced stage than Fig. 9. The slime strings are thicker, and the relation of the granules to the slime strings is more definite. Solution of the callus has commenced, and its outline has become less sharp. $\times 650$.

Fig. I3. Surface view of a large inclined terminal plate. The sieve plates are very numerous and show the distribution of the refringent granules all over them, each granule concealing a slime string beneath it. $\times 75^{\circ}$.

Fig. I4. Surface view of radial wall. The sieve plates are smaller and much less numerous. Refringent granules as in Fig. 13. $\times 600$.

Fig. I5. Surface view of two sieve plates in optical section. The refringent granules conceal the underlying callus and slime strings, except in one or two cases where the granule has been dislodged and the callus has become visible. The median nodule is focused as a dark dot in the midst of the callus basins and is also visible through one or two of the granules. $\quad \times 800$.

Fig. 16. Two sieve plates in surface view. The granules have increased in size. One granule dislodged, showing corresponding underlying callus basin. $\times 800$.

Fig. 17. Longitudinal section of a stage corresponding to surface view in Fig. I6. Paired callus basins, median nodules, and refringent granules, some of which have been dislodged. $\times 800$.

Fig. 18. Tránsverse section of adjoining sieve tubes with lateral plate between them. Three slime strings, considerably thickened, with granules attached, cross the sieve plate. The callus is partially dissolved away, leaving only a thin tubule; the median nodule is still present. $\quad \times 600$.

Fig. 19. Longitudinal section of single sieve plate. Callus, with slime strings not much thickened, but with granules attached on one side of the plate. Callus dissolved away on the other side, one granule sinking in and another detached not far off. $\times 800$.

Fig. 20. Longitudinal section of three slime strings, the top one cut obliquely; the callus is 
completely dissolved. The paired granules of the middle slime string have sunk in unequally. The paired granules of the bottom one are connected by a thick slime string and the median nodule is still visible. $\times$ I,, 000 .

Fig. 21. A longitudinal section showing four slime strings. The granules have sunk more deeply in and almost abut upon one another. $\times$ r,000.

Fig 22. Longitudinal section of a single slime string. The granules connected by a short thick slime string. $\times \mathrm{I}, 000$.

Fig. 23. Longitudinal section of a single slime string. Two granules in contact across the middle lamella. $\times 1,000$.

Fig. 24. Longitudinal section of a single slime string. The granule on one side has sunk in almost to the middle lamella. The granule of the other side has become dislodged in cutting and is lying near. The secondary pit formed by the solution of the callus and from which the granule has been dislodged is visible. The sieve plate is one containing only the single slime string illustrated, and the thickened portions of the wall limiting the sieve plate are visible behind the granules. $\times 1,000$.

Fig. 25. Transverse section of two sieve tubes with a lateral plate connecting them. Thick slime strings with median nodules and paired granules. $\times 420$.

Fig. 26. Transverse section, showing an inclined terminal wall crossing the lumen of the large sieve tube and dividing it into two separate elements. The granules are in various stages of sinking in and the slime strings are thick. Owing to the fact that the wall is inclined, many of the slime strings being cut obliquely are incomplete, and others have had their granules detached. $\times 600$.

Figs. 27 and 28. Transverse sections of a portion of a sieve tube abutting upon phloem parenchyma cells. The pits each contain one, or more rarely two, protoplasmic threads. The median nodule is visible as a dark spot. The wall of the sieve tube is much thicker than that of the phloem parenchyma cell, so that the portion of the thread traversing the wall of the latter is very short and only just recognizable. $\times 600$.

\section{PLATE LV.}

$$
\begin{gathered}
C=\text { cortex } ; E=\text { endodermis } ; P=\text { pericycle } ; P P h=\text { protophloem } ; P h=\text { phloem } ; \\
P P r=\text { phloem parenchyma } ; X=\text { xylem. }
\end{gathered}
$$

Fig. 29. Transverse section of young rhizome. The sieve tubes $(P h)$ are unthickened and the contents have fallen out. The protophloem elements are considerably thickened, and many of them still retain their contents, but no connecting threads are visible. $\times 470$.

Fig. 30. Transverse section of rhizome, old. A group of sieve tubes with lateral sieve plates connecting them. Traversing the sieve plates, the slime strings can be seen indistinctly. The refringent granules are visible as dark dots embedded in the walls in connexion with each slime string, especially on the largest plate of the largest sieve tube $A$; the pits connecting a sieve tube with a phloem parenchyma cell can be distinguished. $\times c .500$.

Fig. 3I. Transverse section of portion of mature rhizome. The distribution of the sieve tubes as a peripheral ring of elements, connected with one another by sieve plates on the radial walls, is shown. The position of the sieve plates is indicated, slightly diagrammatically, by the blue colour of callus. Protophloem is almost absent from this section. $\times 450$.

Fig. 32. Transverse section of portion of rhizome, old. The peripheral row of sieve tubes skirting the xylem is shown. The sieve plates on the radial walls are large, and in places the granules and slime strings can be seen. $\times$ c. 500. 
Annals of Botany.
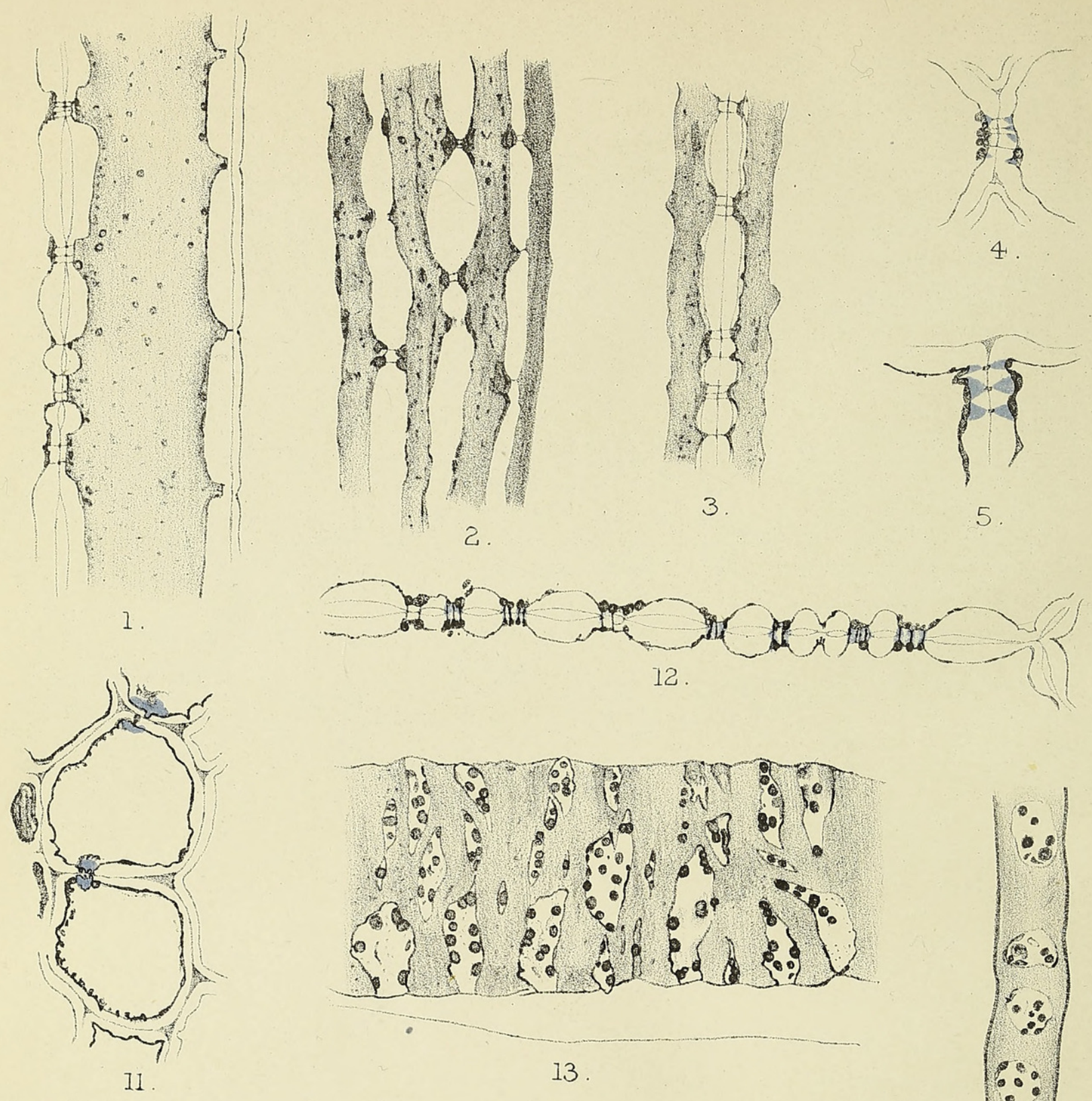

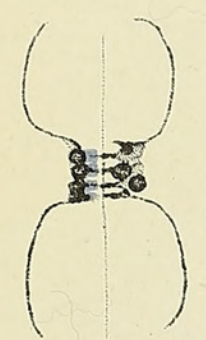

19

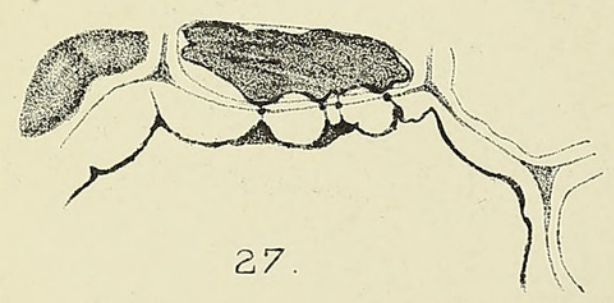

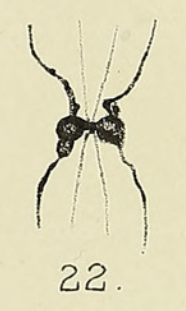

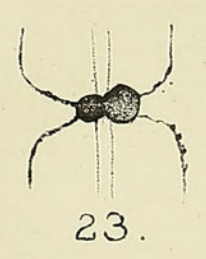

21.
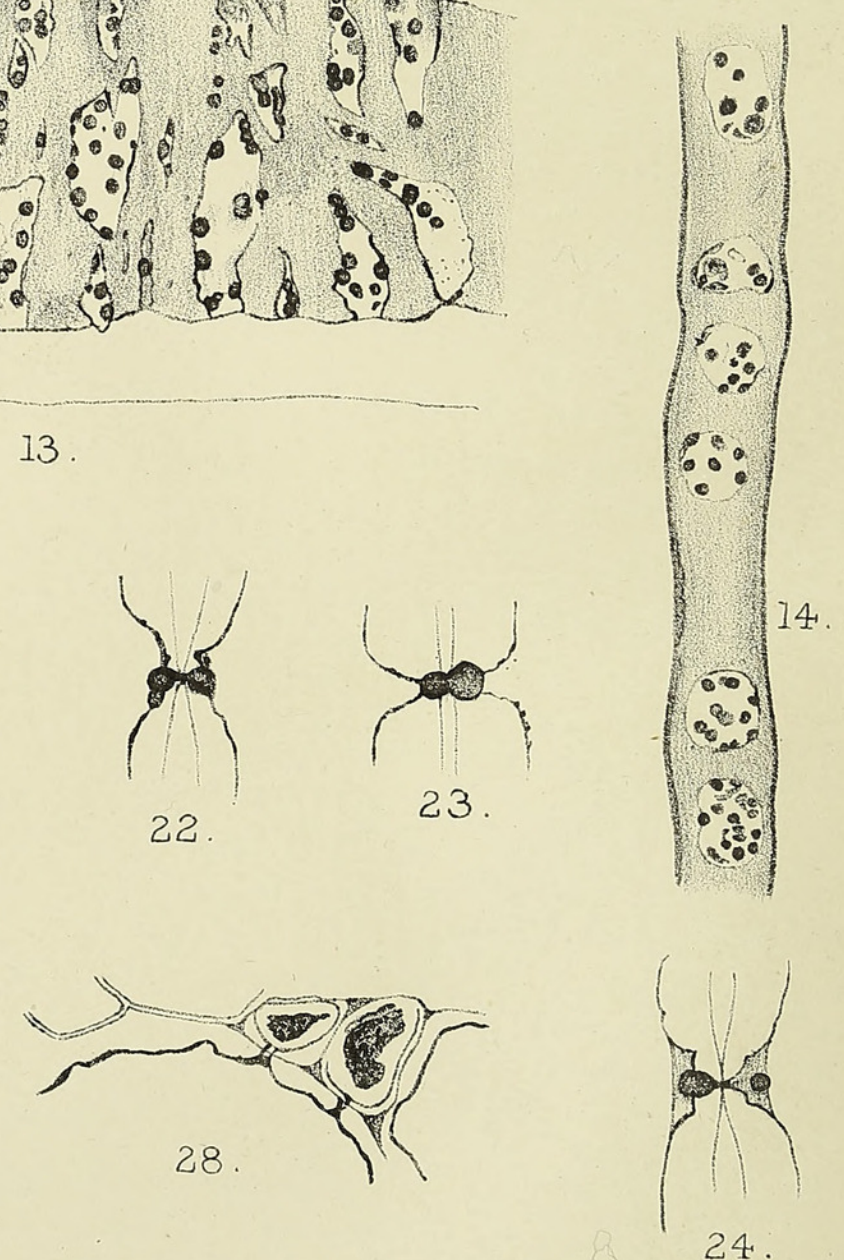

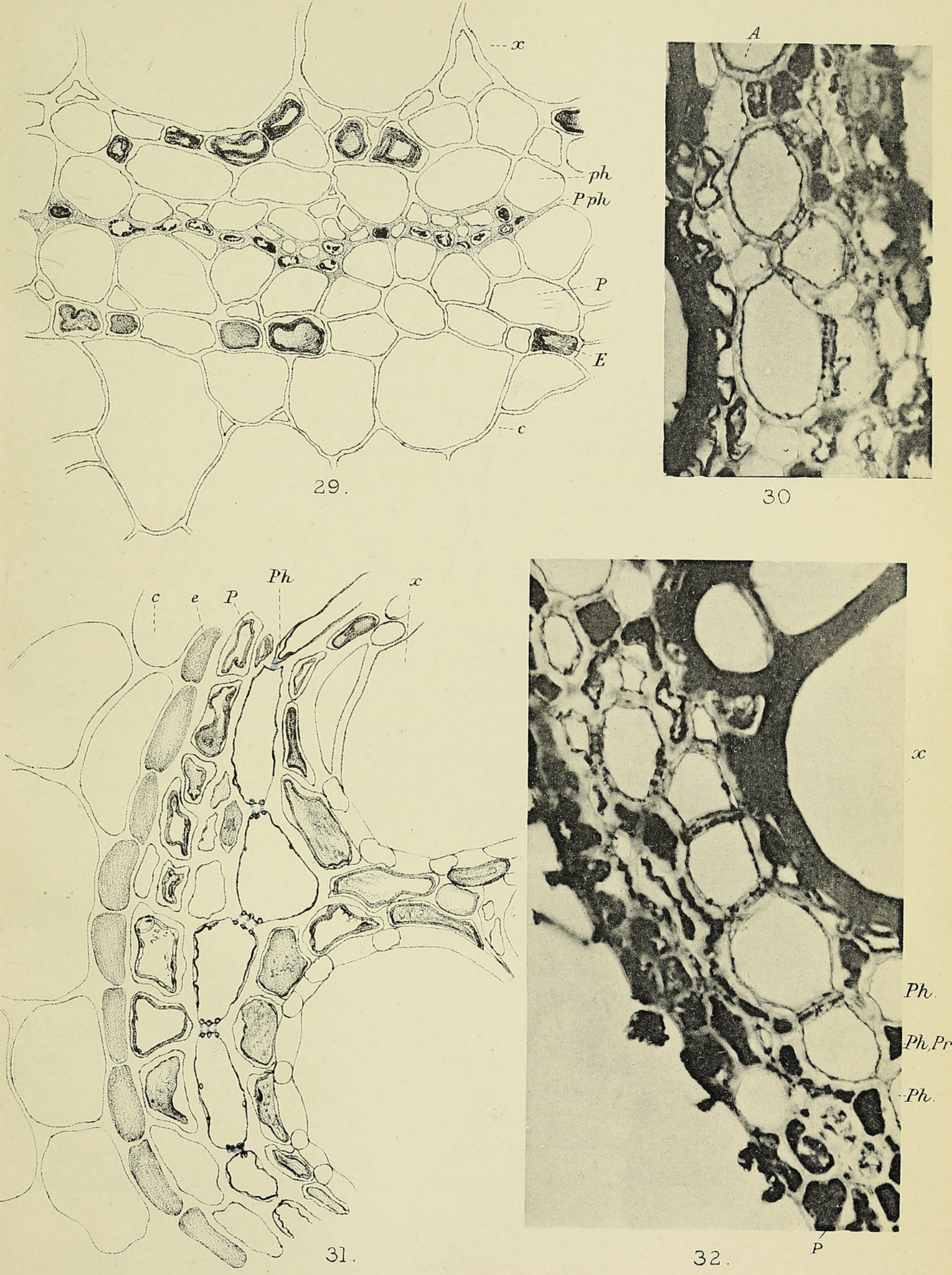


\section{$2 \mathrm{BHL}$ Biodiversity Heritage Library}

Hume, E. M. Margaret. 1912. "The histology of the sieve tubes of Pteridium aquilinum, with some notes on Marsilia quadrifolia and Lygodiumdi chotomum." Annals of botany 26, 573-587. https://doi.org/10.1093/oxfordjournals.aob.a089401.

View This Item Online: https://www.biodiversitylibrary.org/item/236773

DOI: https://doi.org/10.1093/oxfordjournals.aob.a089401

Permalink: https://www.biodiversitylibrary.org/partpdf/319915

\section{Holding Institution}

Smithsonian Libraries

\section{Sponsored by}

Biodiversity Heritage Library

\section{Copyright \& Reuse}

Copyright Status: Not in copyright. The BHL knows of no copyright restrictions on this item.

This document was created from content at the Biodiversity Heritage Library, the world's largest open access digital library for biodiversity literature and archives. Visit BHL at https://www.biodiversitylibrary.org. 